\title{
The Value of Russian to the Reference Librarian
}

On the basis of his experience as reference assistant at the Harvard College Library and of study of the Russian language, $\mathrm{Mr}$. Palmer treats a subject which is of new and growing importance in scholarly libraries.

$\mathrm{T}$ He emergence of Russia as a nation unquestionably in the first rank is one of the major phenomena of our times. This historic fact calls for a re-examination of the place of the Russian language in the world in general and in the American research library in particular.

In number of speakers Russian is surpassed only by Chinese and English. For more than a century Russian literature has been internationally admired. And now the military and, with it, the economic and industrial power of the U.S.S.R. have been strikingly demonstrated to the world. But facts like these, important as they are, do not in themselves guarantee wide study and use of a language outside its own home.

What is more to the point, Soviet research has been very active in a great many fields of knowledge. Insofar as the demands on research libraries are concerned, it is the extent to which scientific, technical, and scholarly material of value is published in a language which counts most heavily. This material-unlike great works of literature-is seldom translated in full, and the investigator who wishes more than an abstract must go to the original.

Russian scholarly production has reached the point where materials in the Russian language have become important not merely to the growing number of specialists in Slavic history and literature but to large numbers of workers in the physical, biological, and social sciences. Russian undoubtedly ranks high among the relatively few languages in which much general scholarly literature is published.

Much, but by no means all, of this material is available in American libraries. For instance, comparison of the list of periodicals on chemistry indexed in the Letopis' Zhurnal'nykh Stater for 1938 with the Union List of Serials shows that most of the titles are available in this country; a few of the most important of them in a dozen or a score of libraries. On the other hand, almost one-third of the titles are not in the Union List at all and the high proportion of incomplete sets is very noticeable.

Use of Russian material, like its availability, is considerable but limited in comparison with the possibilities. Without any desire to accuse our scholars of neglecting matter pertinent to their studies, in all frankness we must admit that the unfamiliarity and reputed difficulty of the Russian language have been powerful restrictive factors. Another element which has no doubt led technologists to discount and neglect Russian findings is a certain reputation for inefficiency which the Russians earned during the early stages of their rapid industrialization.

The war has profoundly changed such attitudes as these. It has dramatized Russian achievements and shown that Russian industrial and technological development 
was greatly underestimated. With the important place the Soviet Union is expected to fill in the postwar world it seems reasonable to expect that we shall find in the future more willingness to acquire some knowledge of the language and less readiness to neglect or minimize the use of Russian sources of information.

\section{Potential Use of Russian}

With the annual level of Russian book production around twenty-eight thousand titles and with several hundred periodicals of sufficient subject value to be indexed, there is plainly a great difference between the present very moderate use of this material in our libraries and the potential use should Russian become no more of a linguistic barrier than German is now. Just how much of this growth will be realized, and how soon, is unpredictable, but in expectation of it one large university library has undertaken an extensive program of instruction in Russian for its cataloging staff.

When this expected trend of greater use materializes, it will be quickly felt among reference librarians, for there are certain special reasons why readers need technical assistance in finding Russian books in a far larger than normal proportion of cases.

In the first place, Russian is written in a non-Roman alphabet. To the American library this means one of two things. It must either isolate its Russian books in a separate catalog or adopt a consistent system of transliteration so that cards in the Slavic alphabet may be interfiled with others. The latter solution is in line with our expectation that Russian books will become less and less a special preserve and more and more used for their subject content by persons other than Slavic specialists, but it gives rise to a number of problems.

There are thirty-two letters in the present-day Russian alphabet. The trans- literation of about half of these (e.g., $\mathrm{A}=$ $a, \mathrm{M}=m, \mathrm{P}=r$ ) is obvious; others offer two or more likely possibilities (for instance the last letter of the alphabet, rendered ia by most American libraries, but $y a$ more commonly outside of library circles, as witness Yalta); while a few letters (such as $\mathrm{X}=k h$ ) are really baffling to the person inexperienced in such matters. Whenever a reader who does not know these rules wishes to look up a name or title in which one of the second or third group of letters occurs near the beginning, he will need assistance. Even a native Russian will need help at this point, as may be seen by comparing the way many Russians write their names in Roman letters with the renderings typical of American library catalogs (cf., Wassiliew, Vasil'ev; Ouchakoff, Ushakov).

\section{Transliteration of Russian}

These examples suggest another aspect of the interalphabetical problem. There is an "international" scheme for the transliteration of Russian, based upon the spelling of certain Slavic languages which use the Roman alphabet, notably Croatian and Czech, and this is rather widely used by scientific men in Central Europe. It is replete with diacritical marks, which is perhaps one reason why it is much more common for various groups to render Russian sounds as nearly as possible by letters indicating the corresponding sounds in their own language. Thus, if there is disagreement among English-speaking writers, librarians, and cartographers over such matters as $i a$ versus $y a$, it is nothing to the differences between the practices of different nations, as will be abundantly evident to anyone who stops to consider the diverse ways in which the Roman alphabet is used by various European languages.

For example, there is a Russian letter which we write $s h$, because it is pronounced like $s h$ in "shelf." To the French- 
man, however, it is like ch in "cher," and to the German, like sch in "Schuh." The Frenchman's ch means something else to us and we use it for another Russian letter (ч); and it represents still a third sound to the German, who uses it for the Russian letter $\mathrm{X}$, for which we have improvised $k h$. The Frenchman has nothing really satisfactory for this last and is apt to use $c h$ for it too, faute de mieux. The results of all this are illustrated by the the name of the Russian musical writer Чешихин. Even in the "international" style this would offer two possibilities: Cešichin (the form actually used by a Czech encyclopedia) or Češihin (the less usual but more logical spelling based on Croatian). In Russian Composers and Musicians, this name appears as Cheshikhin; in Riemann's Musik Lexi$k o n$, as Tscheschichin; and in the French edition of Riemann, as Tchéchichine.

The writer has prepared a table showing the varying renditions by English, French, and German hands of those letters of the Russian alphabet which are thus susceptible of different interpretations, and examples could be multiplied at length; but enough has been said to show that this subject, which we may call comparative transliteration, can be very complicated and confusing. It is obviously a very fruitful field for the reference librarian, especially when we consider that most Russians who come to our shores are more familiar with the German and French ways of using our alphabet than with ours, and that our own scholars will be finding many of their references to Russian materials in continental sources.

\section{Translating Russian}

This suggests a related problem. The first reaction of many persons in dealing with Russian titles is to translate them, sometimes with a warning parenthesis such as Poggendorff's “(russ.)" but often without. The writer particularly remembers an occasion when a reader came to him with the unsolved residuum of a list of references which he had garnered mostly from footnotes in various sources and had been looking up in the catalog. Prominent among them were references to the Zeitschrift des Ministeriums für Völkische Aufklärung and the Bollettino del Ministero dell'Istruzione Pubblica. The routine explanation that things of this sort were cataloged under Germany and Italy proved not to be the solution. Closer scrutiny of the list revealed that the one personal name mentioned was decidedly Russian, and at once the mystery disappeared. All the references were to the Zhurnal Ministerstva Narodnago Prosvieshcheniia, which title had simply been translated without warning into their own languages by the German and Italian writers who referred to it in their footnotes, no doubt under the impression that they were doing their readers a good turn. When the Russian title which has been so treated is not a well-known one like the Zhurnal, the problem-even if we are given fair warning by a parenthetical "in Russian"-becomes one of imagining what the Russian original might have been. Since it is the aim of this article to encourage the study of Russian rather than otherwise, perhaps it will be as well not to go into this aspect of the subject too deeply. Actually it is usually not as difficult as it sounds.

\section{Other Stumbling Blocks}

The field of Russian is strewn with other stumbling blocks of the sort which it is the special province of the reference librarian to remove. The Russians seem to be unusually fond of publication in serial form, with the result that monographs in series and separates from periodicals which are really substantial books, are of ten sought by author and title alone without reference to series or periodical of original publication. 
As we all know, locating material of this sort which has not been analyzed in the catalog is an easy way of making a reputation as a magician. Again, Russian indexing is not always all that it might be and the official book and periodical indexes, excellent in some ways, are very weak in cumulation. In dealing with situations like this, as well as with alphabetical problems, the reference librarian, with his craft of careful examination of reference books and great patience, can often obtain results which are beyond the reach of those whose knowledge of the language is unlimited but who lack the special experience of librarianship.

Hopeful that the reader is now fairly convinced that Russian is a language which will be important for American librarians and that its presence in a library bristles with situations which call for reference skill, we shall now look at the opposite side of the picture. It may be asked whether the time and effort required to study Russian is not more than the demand will justify. Just how much knowledge of the language is needed to cope with the problems suggested above? We have already referred to the reputedly great difficulty of Russian, but it is probably fair to say that this has been somewhat exaggerated. The alphabet is the first obvious barrier that is responsible for so many sins of transliteration and translation, but a few hours' study and a few days' practice will thoroughly demolish this bogey. As for grammar, it is true that the fine points of correct verb usage are very difficult, but reference work deals much more with the simpler noun-adjective system. Insofar as active operation, as distinct from passive recognition, is concerned, the main demand will be for turning the genitive case into the nominative (to obtain corporate entry forms and authors' names ready to be looked up in the catalog) and for filling out endings in words which have been abbreviated. As with most languages, the real problem is vocabulary. Though Russian uses a goodly number of international words, especially in scientific literature, of course the basic vocabulary is Slavic, and its relation to the more familiar Germanic and Italic tongues is distant enough that the recognition of cognate words, which is such an aid to Englishspeaking persons in the study of languages in the two great West European groups, is largely, though not wholly, absent.

However, it is not difficult to make a beginning on the special vocabulary which most concerns the reference librarian. The generic periodical titles (Trudy, Izvestiia, etc.) and words occurring in names of organizations (such as obshchestvo and nauchno-issledovatel'skiu), the names of the principal branches and subbranches of learning, and other words especially frequent in book titles, classification schemes, and indexes, will soon be met with, and a special effort may be made to learn them. The nature of reference work is such that many bibliographical questions may be answered definitely and confidently without involving more than a modicum of linguistic knowledge. The wider vocabulary and knowledge of reference books gradually gained will in due time prepare one for the undertaking of more advanced questions in which a larger body of Russian text must be scanned.

\section{A Formal Course in Russian}

It is, of course, possible to learn Russian by oneself, but in the opinion of the writer a formal course, however brief, is most helpful. On the other hand, a purely linguistic knowledge of Russian is only half the battle. It is the professional skill of the reference librarian and its adaptation to the special problems involved that count.

(Continued on page 23I) 
in the catalog this arrangement spares the older cards the unnecessary wear and tear which they receive under the alphabetical arrangement, since, in the main, readers will use only the more recent cards grouped in front. Finally, when the purchase of a book or the making of analytics of a set is being considered, the time order readily reveals the up-to-dateness of the library's resources in the field in question, a factor which may be decisive in determining whether the purchase or the analytics should be made.

\section{Disadvantages}

There are, of course, certain respects in which the time order shows at a disadvantage. Not infrequently a reader will request a book by an author with a very common name, such as Smith or Wood, first name unknown. If the catalog is full of Wood's, as it is sure to be, the subject approach may be a lifesaver if the arrangement is alphabetical, provided always that the subject is specific enough so that one will not have to search half a dozen subjects. The filing of the cards, too, requires a good deal of care. The corollary of the chronological arrangement is the use of time numbers as book numbers, but because of certain exceptions it is necessary to examine both the imprint date and the time number when filing.

These are minor disadvantages, however, which weigh very lightly in the balance in comparison with what the inverse time order tells by placing the latest card first.

\section{The Value of Russian to the Reference Librarian}

\section{(Continued from page 198)}

In closing we may summarize by saying that even at present a reference librarian with some knowledge of Russian is needed in any library where there are Russian books and there is every sign that the demand for such knowledge of Russian will greatly increase in the postwar years. 